\title{
Pengaruh Kompensasi Dan Motivasi Kerja Terhadap Kinerja Karyawan PT. Sinar Suri Toyota
}

\author{
Margareth Sylvia Sabarofek ${ }^{1}$ \\ ${ }^{1}$ Dosen Jurusan Manajemen, Universitas Papua
}

Received: Juli 2020; Accepted: Agustus 2020; Published: September 2020

\begin{abstract}
Abstrak
PT. Sinar Suri Toyota berada di Kabupaten Manokwari Provinsi Papua Barat. Tujuan Penelitian untuk mengetahui adakah pengaruh pemberian kompensasi dan motivasi kerja terhadap kinerja karyawan. Jenis penelitian yang digunakan adalah penelitian asosiatif dengan menggunakan metode pendekatan kuantitatif. Populasi adalah seluruh karyawan pada bagian bengkel yang bekerja di PT. Sinar Suri Toyota Manokwari dengan jumlah 32 orang. Namun pada saat pengambilan data adanya pandemi Covid-19 sehingga pengambilan data melalui google from. Metode pengumpulan data yang digunakan adalah pengamatan dan angket. Teknik analisis data yang digunakan adalah regresi linear berganda. Untuk melihat adanya pengaruh variabel independen kompensasi dan motivasi kerja terhadap variabel dependen kinerja karyawan melalui uji hipotesis. Ada dua cara yang dipakai untuk mengukur variabel independen dan dependen dengan berdasarkan uji t dan uji F. Dari hasil penelitian berdasarkan uji parsial (uji t) untuk variabel kompensasi dan motivasi kerja terhadap kinerja karyawan. Untuk nilai signifikan lebih kecil dari taraf kesalahan $(0,000>0,05)$ dan nilai signifikan lebih kecil dari taraf kesalahan $(0,032>0,05$, sehingga $\mathrm{H} 0$ tolak dan Ha diterima, artinya bahwa secara parsial variabel kompensasi dan motivasi kerja berpengaruh signifikan terhadap variabel kinerja karyawan. Sedangkan pengujian secara simultan (uji F) variabel kompensasi dan motivasi kerja terhadap variabel kinerja karyawan dengan nilai signifikan lebih kecil dari taraf kesalahan $(0,000>0,05)$ sehingga $\mathrm{H} 0$ ditolak dan Ha diterima, artinya bahwa secara simultan, kompensasi dan motivasi sangat mempengaruhi kinerja karyawan.
\end{abstract}

Kata kunci: kompensasi, motivasi kerja, kinerja karyawan

\begin{abstract}
PT. Sinar Suri Toyota is located in Manokwari Regency, West Papua Province. The research objective was to see whether compensation and work motivation had an effect on employee performance. This type of research is associative research using a quantitative approach method. The population is all employees in the workshop who work at PT. Sinar Suri Toyota Manokwari with a total of 32 people. However, at the time of data collection, there was a pandemic Covid-19 so that data retrieval via google was from. The data methods used were observation and questionnaires. The data analysis technique used is multiple linear regression. To see the effect of the independent variable compensation and work motivation on the dependent variable employee performance through hypothesis testing. There are two ways used to measure the independent and dependent variables based on the $t$ test and the F test. From the research results based on the parti al test ( $t$ test) for the variable compensation and work motivation on employee performance. For a significant value smaller than the error error $(0.000>0.05)$ and a significant value smaller than the error error $(0.032>0.05$, so that $\mathrm{HO}$ is rejected and $\mathrm{Ha}$ is accepted, meaning that partially the compensation and work motivation variables have a significant effect on the variable Employee performance While simultaneous testing ( $F$ test) of compensation and motivation variables on employee performance variables with a significant value smaller than the error error (0.000> 0.05) so that $\mathrm{HO}$ is rejected and $\mathrm{Ha}$ is accepted, meaning that simultaneously, compensation and motivation greatly affect employee performance.
\end{abstract}

Keywords: compensation, work motivation, employee performance 
How to Cite: Sabarofek, M.S. (2020). Pengaruh Kompensasi Dan Motivasi Kerja Terhadap Kinerja Karyawan PT. Sinar Suri Toyota. JFRES: Journal of Fiscal and Regional Economy Studies, 3 (2), 37 - 46.

Corresponding author:
E-mail: margarethsylvia83@gmail.com

\section{PENDAHULUAN}

Dalam suatu organisasi sangat dibutuhkan seorang manajer untuk mengatur dan mengelola sumber daya yang ada dalam organisasi tersebut. Tugasnya manajer adalah menetapkan tujuan perusahaan, memberikan kepemimpinan untuk mencapai tujuan perusahaan serta membuat keputusan bagaimana menggunakan sumber daya yang ada dalam organisasi untuk mencapau tujuan yang telah ditetapkan (Solihin, 2009). Sebab sumber daya manusia adalah pegawai yang siap, mampu, dan siaga dalam mencapai tujuan-tujuan organisasi menurut Werther dan Davis dalam bukunya Sutrisno (2009). Untuk mencapai tujuan perusahaan perlu adanya perencanaan yang baik untuk mengatur sumber daya manusia dalam melakukan pekerjaan. Melalui perencanaan sumber daya manusia akan meningkatkan kinerja seorang karyawan secara signifikan. Perlu adanya kontribusi dari perusahaan untuk meningkatkan kinerja karyawan dengan pemberian kompensasi yang sesuai dengan keinginan karyawan tersebut atau berdasarkan penilaian kinerja karyawan dari berbagai sumber di perusahaan tersebut dan juga motivasi karyawan tersebut dalam bekerja di perusahaan. Pentingnya kompensasi bagi kinerja karyawan sangat berpengaruh signifikan terhadap perilaku seseorang. Kinerja karyawan bekerja namun kompensasi tidak diberikan dengan baik maka akan memunculkan dua faktor yaitu, karyawan malas bekerja dan karyawan mengundurkan diri. Maka perlu adanya pemberian kompensasi yang baik karena kompensasi merupakan sesuatu yang diterima oleh tenaga kerja sebagai pengganti kontribusi jasa mereka pada perusahaan (Zainal, ddk, 2018).

Pemberian kompensasi yang baik dan sesuai dengan keahlian, kemampuan, dan profesi pendidikan akan dapat meningkatkan kesadaran karyawan terhadap tanggung jawab kerjanya agar tidak terjadi kecemburuan sesama mitra kerja lainnya apabila terjadi perbedaan pemberian kompensasi yang diberikan. Sehingga setiap kinerja karyawan harus mempunyai strategi untuk menerapkan empat fungsi-fungsi manajemen (Planning, Organizing, Actuacting, dan Controlling) dalam perusahaan tersebut. Fungsi-fungsi manajemen tersebut tidak dapat terlaksana dengan baik apabila kompensasi yang diberikan tidak sesuai dengan apa yang diharapkan karyawan dan juga mengurangi motivasi karyawan tersebut dalam bekerja.

Motivasi (motivation) berasal dari bahasa latin movere yang artinya penggerak (Winardi, 2002). Menurut Hasibuan (2007) motivasi adalah pemberian daya penggerak yang menciptakan kegairahan kerja seseorang agar mereka mau bekerja dengan segala daya upayanya untuk mencapai kepuasannya. Dengan demikian motivasi kerja mempunyai sifat yang tidak lepas dari sifat manusia itu sendiri, dimana manusia secara individual mempunyai kualitas diri yang berbeda-beda antar mitra kerja yang lain, aktualisasi diri untuk meningkatkan prestasinya. Motivasi kerja juga dapat dipengaruhi secara internal (dari diri sendiri) dan eksternal (dari orang lain). Oleh karena itu dengan adanya motivasi kerja setiap karyawan akan memberikan yang terbaik yang ada pada dirinya agar kinerja dirinya sendiri meningkat sekaligus meningkatkan kemampuan, loyalitas, keahlian dibidang tersebut, dan etika agar mempengaruhi kinerja perusahaan. Sehingga faktor seperti pemberian kompensasi dan motivasi kerja setiap kinerja karyawan yang bekerja dalam organisasi tersebut, dapat meningkatkan kinerja karyawan secara efektif dan efisien. Sebab bila kedua faktor tersebut berjalan sebagaimana mestinya maka finansial dan waktu yang dikeluarkan untuk produktivitas dapat ditekan sehingga tidak banyak mengeluarkan fisik dan finansial yang seharusnya tidak perlu digunakan.

Pemberian kompensasi yang tidak sesuai dengan yang diharapkan kinerja karyawan dan juga motivasi akan menyebabkan menurunnya semangat kerja karyawan dan juga kurangnya inisiatif didalam pekerjaannya. Sehingga kinerjanya pun kurang maksimal atau lebih tepatnya kurang dimaksimalkan, tentu hal 
tersebut dapat mempengaruhi kinerja organisasi beberapa lini.

Satu-satunya Sub-Dealer yang ada di Manokwari Provinsi Papua Barat adalah PT. Sinar Suri yang bergerak dalam hal penjualan kendaraan, servis, dan penjualan suku cadang, yang dipimpin oleh Kepala Cabang sekaligus owner yang membawahi beberapa divisi seperti, pemasaran, purna jual, dan suku cadang. Lingkungan kerja dan suasana kerja yang bersifat kekeluargaan dalam PT. Sinar Suri menggambarkan sangat nyaman tempat kerjanya dengan berbagai fasilitas yang menunjang kinerja mereka. Berdasarkan penjelasan diatas maka peneliti tertarik meneliti secara empiris tentang kompensasi dan motivasi kerja terhadap kinerja karyawan, yang adapun teori-teori yang mendasari penelitian sebagai berikut.

Kompensasi merupakan salah satu bentuk penghargaan yang diberikan dari perusahaan kepada kinerja karyawan atas prestasi (hasil) yang diberikan pada perusahaan. Menurut Dessler (2015), kompensasi (compentation) meliputi semua bentuk bayaran yang diberikan kepada karyawan dan timbul dari hubungan kerja mereka. Kompensasi juga merupakan sesuatu yang diterima oleh tenaga kerja sebagai pengganti kontribusi jasa mereka pada perusahaan (Veithzal, ddk, 2018). Sebab kompensasi adalah salah satu alternatif yang mampu meransang kinerja karyawan untuk meningkatkan semangat kerja dan mempertahan kinerja karyawan yang mempunyai kompetensi dalam bidang tertentu serta organisasi tersebut. Sedangkan kompensasi menurut Hasibuan (2010) adalah semua pendapatan yang diberikan dalam bentuk penghargaan maupun uang, baik secara langsung maupun tidak langsung yang diterima kinerja sebagai imbalan atas jasa yang diberikan kepada perusahaan.

Menurut Veithzal, dkk (2018) kompensasi terbagi menjadi dua jenis yaitu kompensasi finansial langsung dan tidak langsung. Kompensasi langsung terdiri dari pembayaran karyawan dalam bentuk upah, gaji, bonus, atau komisi. Sedangkan kompensasi finansial tidak langsung, atau benefit, terdiri dari semua pembayaran yang tidak tercakup dalam kompensasi finansial langsung yang meliputi liburan, berbagai macam asuransi, jasa seperti perawatan anak atau kepedulian keagamaan, dan sebagainya. Penghargaan nonfinansial seperti pujian, menghargai diri sendiri, dan pengakuan yang dapat mempengaruhi motivasi kerja karyawan, produktivitas, dan kepuasan.

Secara umum tujuan kompensasi adalah untuk membantu perusahan mencapai tujuan keberhasilan strategi perusahan dan menjamin terciptanya keadilan internal dan eksternal (Veithzal, ddk, 2018). Tujuan kompensasi adalah sebagai berikut:

a. Memperoleh SDM yang Berkualitas. Kompensasi yang sangat baik dibutuhkan untuk memberi daya tarik kepada para pelamr. Tingkat pembayaran harus responsif terhadap penawaran dan permintaan passar kerja karena para pengusaha berkompetensi untuk mendapatkan karyawan yang diharapkan.

b. Mempertahankan karyawan yang ada. Para karyawan dapat keluar jika besaran kompensasi tidak kompetitif dan akibatnya akan menimbulkan perputaran karyawan yang semakin tinggi.

c. Menjamin keadilan. Manajemen kompensasi selalu berupa agar keadilan internal dan eksternal terwujud. Keadilan internal mensyaratkan bahwa pembayaran dikaitkan dengan nilai relatif sebuah pekerjaan sehingga pekerjaan yang sama dibayar dengan besaran yang sama. Sedangkan keadilan eksternal yaitu pembayaran terhadap pekerja merupakan yang dapat dibandingkan dengan perusahan lain dipasar kerja.

d. Penghargaan terhadap perilaku yang diinginkan. Pembayaran hendaknya memperkuat perilaku yang diinginkan dan bertindak sebagai insentif untuk perbaikian perilaku dimasa depa, rencana kompensasi efektif, menghargai kinerja, ketaatan, pengalaman, tanggung jawab, dan perilaku-perilaku lainnya.

e. Mengendalikan biaya. Sistem kompensasi yang rasional membantu perusahan memperoleh dan mempertahankan para karyawan dengan biaya yang beralasan. Tanpa kompensasi efektif, bisa jadi pekerja dibayar di bawah atau di atas standar.

f. Mengikuti aturan hukum. Sistem gaji dan upah yang sehat mempertimbangkan faktorfaktor legal yang dikeluarkan pemerintah dan menjamin pemenuhan kebutuhan karyawan.

g. Memfasilitasi pengertian. Sistem manajemen kompensasi hendaknya dengan muda dipahami oleh spesialis SDM, manajer operasi, dan para karyawan. 
h. Meningkatkan efisiensi administrasi. Program pengupahan dan penggajian hendaknya dirancang untuk dapat dikelola dengan efesien, membuat sistem informasi SDM optimal, meskipun tujuan ini hendaknya sebagai pertimbangan sekunder dibandingkan dengan tujuan-tujuan lain.

Menurut Mangkunegara (2008) ada beberapa faktor yang dapat mempengaruhi kebijakan kompensasi antara lain sebagai berikut:

1. Faktor pemerintah. Pengaruh pemerintah yang berhubungan dengan penentuan standar gaji, pajak penghasilan, penetapan harga bahan baku, biaya transportasi, inflasi maupun devaluasi yang sangat berpengaruhi pada perusahaan dalam mengambil kebijakan untuk pemberian kompensasi pada pegawai.

2. Penawaran bersama antara perusahaan dan pegawai. Kebijakan dalam menentukan kompensasi dapat dipengaruhi pula pada saat terjadinya tawar menawar mengenai besarnya upah yang harus diberikan oleh perusahaan kepada pegawainya. Hal ini terutama dilakukan oleh perusahaan dalam merekrut pegawai yang mempunyai keahlian dalam bidang tertentu yang sangat dibutuhkan di perusahaan.

3. Standar dan biaya hidup pegawai. Kebijakan kompensasi perlu mempertimbangkan standar dan biaya hidup minimal pegawai. Hal ini karena kebutuhan dasar pegawai harus terpenuhi. Dengan tepenuhinya kebutuhan dasar pegawai dan keluarganya, maka pegawai akan merasa aman. Terpenuhinya kebutuhan dasar dan rasa aman pegawai dapat bekerja dengan penuh motivasi untuk mencapai tujuan perusaahaan. Banyak penelitian menunjukan bahwa ada korelasi tinggi antara motivasi kerja pegawai dan prestasi kerjanya, ada korelasi positif antara motivasi kerja dan pencapaian tujuan perusahaan.

4. Ukuran perbandingan upah. Kebijakan dalam menentukan kompensasi dipengaruhi pula oleh ukuran besar kecilnya perusahaan, tingkat pendidikan pegawai, masa kerja pegawai. Artinya, perbandingan tingkat upah pegawai perlu memperhatikan tingkat pendidikan, masa kerja, dan ukuran perusahaan.

5. Permintaan dan persediaan. Dalam menentukan kebijakan kompensasi pegawai perlu mempertimbangkan tingkat persediaan dan permintan pasar. Artinya, kondisi pasar pada saat itu perlu dijadikan bahan pertimbangan dalam menentukan tingkat upah pegawai.

6. Kemampuan membayar. Dalam menentukan kebijakan kompensasi pegawai perlu didasarkan pada kemampuan perusahaan dalam membayar upah pegawai. Artinya, jangan sampai menentukan kebijakan kompensasi diluar batas kemampuan yang ada pada perusahaan

Motivasi menurut Veitzhal, dkk (2018) adalah Serangkaian sikap dan nilai-nilai yang mempengaruhi individu untuk mencapai hal yang spesifik sesuai dengan tujuan individu. Sebab motivasi merupakan suatu yang invisible yang memberikan kekuatan untuk mendorong individu untuk bertingkah laku dalam mencapai tujuan. Menurut Kafer dalam bukunya Solihin (2009) mengemukakan motivasi (motivation) adalah kekuatan psikologi yang akan menentukan arah dari perilaku seseorang (direction of a person's behavior), tingkat upaya (level of effort) dari seseorang dan tingkat ketegaran (level og persistence) pada saat orang itu dihadapkan pada berbagai rintangan.

Pendekatan-pendekatan motivasi (Bangun, 2012) yaitu:

1. Pendekatan tradisional, berdasarkan pandangan ini, umumnya pekerja dianggap malas bekerja, dan hanya dapat dimotivasi dengan memberikan penghargaan yang berwujud uang. Pada umumnya para pekerja kurang bertanggung jawab atas pekerjaannya, sehingga untuk meningkatkan produktivitas kerja mereka harus dimotivasi dengan penghargaan dalam bentuk uang. Sejalan dengan meningkatnya efisiensi, karyawan yang dibutuhkan untuk tugas tertentu akan dapat dikurangi

2. Pendekatan hubungan manusia selalu dikaitkan dengan pendapat Elton Mayo. Mayo menemukan bahwa kebosanan dan pengulangan berbagai tugas merupakan faktor yang dapat menurunkan motivasi, sedangkan kontak sosial membantu dalam menciptakan dan mempertahankan motivasi. Sebagai kesimpulan dari pendekatan ini, manajer dapat memotivasi karyawan dengan membuat mereka berguna dan lebih penting.

3. Pendekatan sumber daya manusia menyatakan bahwa para karyawan dimotivasi oleh banyak faktor, tidak hanya uang atau keinginan untuk mencapai kepuasan, tetapi juga kebutuhan untuk berprestasi dan memperoleh 
pekerjaan yang berarti. Sebagai contoh, pada teori $\mathrm{X}$ dan $\mathrm{Y}$ mengasumsikan terdapat dua sifat manusia dalam menghadapi suatu pekerjaan, satu sisi melaksanakannya secara aktif, sedangkan pandangan lain menanggapinya secara pasif.

Kinerja merupakan output yang dihasilkan secara kuantitas dan kualitas yang dicapai oleh karyawan atas tugas dan tanggung jawab yang diberikan dari perusahan kepadanya dalam waktu tertentu. Kinerja merupakan hal nyata yang ditampilkan oleh setiap pribadi orang secara nyata sebagai prestasi kerja yang dihasilkan oleh tenaga kerja sesuai dengan fungsi peranan dalam perusahaan. Kinerja karyawan (work performance) merupakan hasil kerja secara kualitas dan kuantitas yang digapai oleh karyawan dalam menjalankan tugasnya sesuai dengan tanggung jawab yang diberikan kepadanya (Mangkunegara, 2008). Menurut Wibowo (2007) berpendapat bahwa kompensasi adalah kontra prestasi terhadap penggunaan jasa yang telah diberikan oleh tenaga kerja. Kemudian menurut Bangun (2012) kinerja (performance) adalah hasil pekerjaan yang dicapai seseorang berdasarkan persyaratanpersyaratan pekerjaan (job requirement). Berdasarkan pendapat para ahli diatas, maka dapat disimpulkan bahwa kinerja (performance) adalah hasil atau prestasi kerja berdasarkan perilaku yang ditampilkan seseorang dalam mengerjakan/menyelesaikan tanggung jawab yang diberikan dari perusahan sesuai dengan target yang ditentukan dalam waktu tertentu.

Penilaian kinerja (performance appraisal) adalah sistem formal untuk menilai dan mengevaluasi kinerja tugas individu atau tim (Mondy, 2008). Penilaian kinerja meliputi umpan balik kepada pegawai itu dan menentukan apakah dan bagaimana kinerja dapat diperbaiki. Penilaian kinerja yang efektif memerlukan pengendalian umpan balik yang efektif (Gibson, dkk, 1997). Karena penilaian kinerja melibatkan individu yang menilai kualitas dan kuantitas kinerja pekerja individu lain, prosesnya sering kali bersifat emosional; penilaian ini bersifat mengaktifkan gagasan dan persepsi tentang keadilan dan perlakuan yang sama. Penilaian kinerja juga mengacu pada suatu sistem formal dan terstruktur yang digunakan untuk mengukur, menilai dan mempengaruhi sifat-sifat yang berkaitan dengan pekerjaan. Penilaian kinerja merupakan prosedur yang meliputi penetapan standar kinerja, penilaian kinerja aktual terhadap prosedur yang telah ditetapkan, dan umpan balik karyawan. Tujuannya adalah untuk memotivasi kinerja tersebut untuk berkinerja lebih tinggi (Kusumah, 2015).

Faktor yang paling muncul di perusahan adalah ilmu tentang pekerjaannya, leadership, initiative, quality ofwork, cooperation, creativity, planning, communication, intelligence (kecerdasan), effort, motivation, and organization. Dari aspek-aspek yang dinilai dapat dikelompokan menjadi:

1. Kemampuan teknis, yaitu kemampuan menggunakan pengetahuan, metode, teknik, dan peralatan yang dipergunakan untuk melaksanakan tugas serta pengalaman dan pelatihan yang diperolehnya.

2. Kemampuan konseptual, yaitu kemampuan untuk memahami kompleksitas perusahan dan penyesuaian bidang gerak dari unit masingmasing ke bidang operasional secara menyeluruh.

3. Kemampuan hubungan interpersonal, yaitu antara lain kemampuan untuk bekerja sama dengan orang lain, memotivasi karyawan, melakukan negosiasi, dan lain-lain.

Indikator yang dipakai untuk mengukur kinerja pegawai yakni. jumlah pekerjaan, kualitas pekerjaan, ketepatan waktu, kehadiran dan kemampuan kerja sama (Bangun, 2012). Adapun Indikator sebagai berikut:

1. Jumlah pekerjaan, yang dihasilkan individu atau kelompok sebagai persyaratan yang menjadi standar pekerjaan. Setiap pekerjaan memiliki persyaratan yang berbeda sehingga menuntut pegawai harus memenuhi persyaratan tersebut baik pengetahuan, keterampilan, maupun yang sesuai.

2. Kualitas pekerjaan, setiap pegawai dalam organisasi harus memenuhi persyaratan tertentu untuk dapat menghasilkan pekerjaan. Setiap pekerjaan memiliki standar kualitas yang harus disesuaikan oleh pegawai untuk dapat mengerjakan sesuai ketentuan.

3. Ketepatan waktu, jenis pekerjaan harus diselesaikan tepat waktu, karena memiliki ketergantungan atas pekerjaan lainnya.

4. Kehadiran, kehadiran pegawai selama delapan jam sehari untuk lima hari kerja. 
5. Kemampuan kerja sama, untuk jenis pekerjaan tertentu mungkin harus diselesaikan oleh dua orang pegawai atau lebih, sehingga kerja sama antar pegawai sangat dibutuhkan.

Menurut Mulyadi (2016), tujuan penilaian kinerja adalah sebagai berikut:

1. Untuk mengetahui prestasi yang didapatkan sebelum karyawan itu bekerja

2. Untuk memotivasi dan bertanggung jawab seorang karyawan/ pekerja

3. Untuk mengambil keputusan dalam memberikan kompensasi agar adil seperti kenaikan gaji, pemberian bonus, THR, dan insentif lainnya

4. Untuk meningkatkan etos kerja dan mendorong semangat kerja serta meningkatkan produktivitas karyawan

5. Untuk mendapatkan umpan balik karyawan yang hasilnya untuk memperbaiki karyawan apabila dalam penilaian kinerja terdapat hasil yang kurang baik. Sebaliknya untuk memberikan penghargaan jika dalam penilaian terdapat prestasi yang baik

6. Untuk mendapatkan informasi yang akurat dalam mengambil keputusan pemberian kompensasi lain bonus, insentif, dan lain-lain.

Sekaran dalam bukunya Sugiyono (2012), kerangka berpikir merupakan model konseptual tentang bagaimana teori berhubungan dengan faktor yang telah diidentifikasi sebagai masalah yang penting. Adapun kerangka berpikir sebagai berikut:

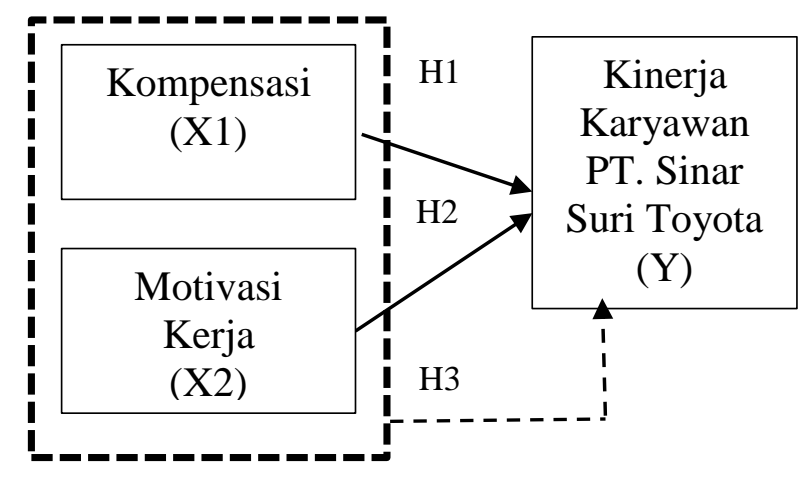

Keterangan:

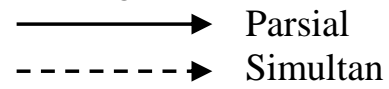

Gambar 1. Kerangka Konseptual Penelitian

Hipotesis dalam penelitian ini adalah:
H01: Diduga kompensasi tidak berpengaruhi signifikan terhadap kinerja karyawan PT. Sinar Suri Toyota

Ha1: Diduga kompensasi berpengaruhi signifikan terhadap kinerja karyawan PT. Sinar Suri Toyota

H02: Diduga motivasi kerja tidak berpengaruhi signifikan terhadap kinerja karyawan PT. Sinar Suri Toyota

Ha2: Diduga motivasi kerja berpengaruhi signifikan terhadap kinerja karyawan PT. Sinar Suri Toyota

H03: Diduga kompensasi dan motivasi kerja tidak berpengaruh signifikan terhadap kinerja karyawan PT. Sinar Suri Toyota

Ha3: Diduga kompensasi dan motivasi kerja berpengaruh signifikan terhadap kinerja karyawan PT. Sinar Suri Toyota

\section{METODE PENELITIAN}

Jenis penelitian yang peneliti gunakan adalah penelitian asosiatif. Dimana metode yang digunakan dalam penelitian ini adalah pendekatan kuantitatif. Data kuantitatif adalah jenis data yang diukur atau dihitung secara langsung, yang berupa informasi atau penjelasan yang dinyatakan dengan bilangan atau berbentuk angka.

Jumlah populasi dalam penelitian ini adalah seluruh karyawan pada bagian bengkel yang bekerja di PT. Sinar Suri Toyoya Manokwari yang berjumlah 32 responden dengan menggunakan metode Non probability sampling. Menurut Sugiyono (2012) Nonprobability Sampling adalah teknik pengambilan sampel yang tidak memberi peluang/kesempatan sama bagi setiap unsur atau anggota populasi untuk dipilih menjadi sampel. Penelitian ini data yang dipakai ada dua jenis sumber data yaitu, sumber data primer melalui pembagian angket juga survei langsung dan sumber data sekunder.

Adapun analisis data yang digunakan antara lain: Uji validitas dan realibilitas, uji koefisien determinasi $\left(R^{2}\right)$, uji parsial (uji t), uji simultan (uji F) serta analisis regresi linear berganda. Adapun rumus yang digunakan sebagai berikut:

$$
\gamma=\alpha+b_{1} X_{1}+b_{2} X_{2}+e
$$

Keterangan:

$\gamma \quad=$ Variabel Kinerja Karyawan

$\alpha=$ Nilai Konstanta 
$\mathrm{X} 1=$ Variabel Kompensasi

$\mathrm{X} 2$ = Variabel Motivasi Kerja

$\beta 1=$ Koefisien untuk Variabel Kompensasi

$\beta 2=$ Koefisien untuk Variabel Motivasi Kerja

$\mathrm{e} \quad=$ Tingkat kesalahan (error term)

\section{HASIL DAN PEMBAHASAN}

Tabel 1 menunjukkan uji validitas dimana $r$ hitung > dari $r$ tabel maka dapat disimpulkan semua item pertanyaan dinyatakan valid.

Hasil uji reliabilitas pada tabel 2. diatas menunjukkan angka bahwa nilai Cronbach Alpha dari masing-masing variabel Tabel 1. Uji Validitas menunjukkan angka >0,60. Dapat disimpulkan bahwa semua variabel dalam penelitian ini dinyatakan reliabel.

Tabel 2. Hasil uji reabilitas

\begin{tabular}{|c|c|c|c|}
\hline Variabel & $\begin{array}{c}\text { Cronbach's } \\
\text { Alpha }\end{array}$ & $\begin{array}{c}\text { Cut } \\
\text { of } \\
\text { Point } \\
\end{array}$ & Ket. \\
\hline Kompensasi (X1) & 0,880 & 0,60 & Reliabel \\
\hline $\begin{array}{l}\text { Motivasi } \\
\text { Kerja (X2) }\end{array}$ & 0,799 & 0,60 & Reliabel \\
\hline $\begin{array}{l}\text { Kinerja } \\
\text { Karyawan (Y) }\end{array}$ & 0,903 & 0,60 & Reliabel \\
\hline
\end{tabular}

Sumber: Data primer yang diolah, 2020

\begin{tabular}{lcccc}
\hline Variabel & Pernyataan & $\begin{array}{c}\text { Pearson } \\
\text { Correlation }\end{array}$ & Nilai Sig & Keterangan \\
\hline Kompensasi & X1 & 0,254 & 0,05 & Valid \\
& X2 & 0,280 & 0,05 & Valid \\
& X3 & 0,400 & 0,05 & Valid \\
& X4 & 0,390 & 0,05 & Valid \\
X5 & 0,498 & 0,05 & Valid \\
X6 & 0,631 & 0,05 & Valid \\
& X7 & 0,751 & 0,05 & Valid \\
& X8 & 0,739 & 0,05 & Valid \\
& X9 & 0,613 & 0,05 & Valid \\
& X10 & 0,413 & 0,05 & Valid \\
& X1 & 0,498 & 0,05 & Valid \\
Xotivasi Kerja & X2 & 0,545 & 0,05 & Valid \\
& X3 & 0,382 & 0,05 & Valid \\
& X4 & 0,650 & 0,05 & Valid \\
& X5 & 0,598 & 0,05 & Valid \\
& X6 & 0,587 & 0,05 & Valid \\
& X7 & 0,334 & 0,05 & Valid \\
& X8 & 0,651 & 0,05 & Valid \\
& X9 & 0,601 & 0,05 & Valid \\
& X10 & 0,537 & 0,05 & Valid \\
& Y1 & 0,431 & 0,05 & Valid \\
& Y2 & 0,377 & 0,05 & Valid \\
& Y3 & 0,373 & 0,05 & Valid \\
& Y4 & 0,483 & 0,05 & Valid \\
& Y5 & 0,308 & 0,05 & Valid \\
Y6 & 0,306 & 0,05 & Valid \\
& Y7 & 0,320 & 0,05 & Valid \\
& Y8 & 0,266 & 0,05 & Valid \\
\hline
\end{tabular}

Sumber: Data primer yang diolah, 2020

\section{Tabel 3. Hasil uji t}

Coefficients $^{\mathrm{a}}$

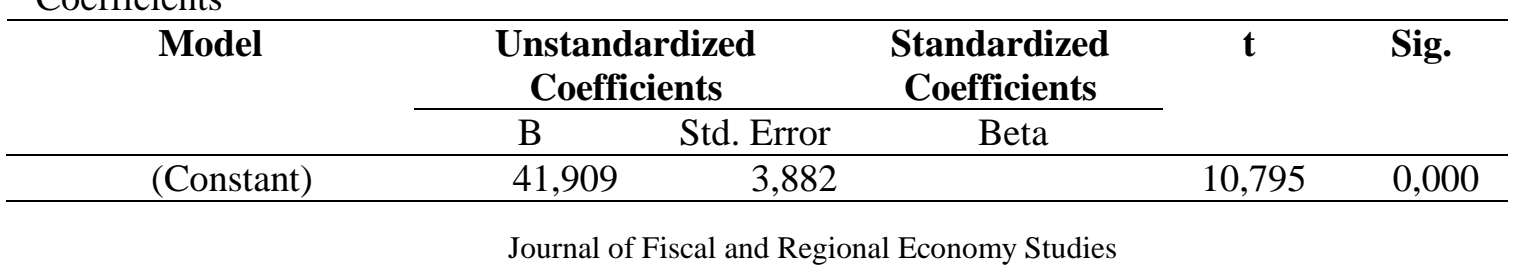




\begin{tabular}{crrrrr}
\hline Kompensasi & 0,120 & 0,125 & $-0,022$ & $-0,095$ & 0,000 \\
\hline Motivasi Kerja & 0,137 & 0,130 & 0,242 & 1,050 & 0,032 \\
\hline
\end{tabular}

Sumber: Data primer yang diolah, 2020

Berdasarkan tabel 3. dapat dijelaskan sebagai berikut:

1. Kompensasi (X1) memiliki nilai signifikan sebesar 0,000. Berarti nilai signifikan lebih kecil dari $0,05 \quad(0,000<0,05) \quad$ artinya variabel kompensasi (X1) secara parsial berpengaruh terhadap variabel kinerja karyawan (Y). Sehingga dapat disimpulkan bahwa H01 ditolak dan Ha1 diterima.

2. Motivasi Kinerja (X2) memiliki nilai signifikan sebesar 0,302. Berarti nilai signifikan lebih besar dari $0,05 \quad(0,032>0,05)$. Artinya variabel motivasi kerja (X2) secara parsial berpengaruh terhadap variabel kinerja karyawan (Y). Sehingga dapat disimpulkan bahwa $\mathrm{H} 02$ ditolak dan $\mathrm{Ha} 2$ diterima.

Berdasarkan tabel 4. diatas terlihat bahwa nilai siginifikan variabel kompensasi (X1), dan motivasi kerja (X2), secara simultan berpengaruh terhadap variabel kinerja $(\mathrm{Y})$. Hal ini ditunjukkan dengan nilai signifikan sebesar $0,000<0,05$. Sehingga dapat disimpulkan bahwa $\mathrm{H} 03$ ditolak dan Ha3 diterima.

Tabel 4. Hasil Uji Simultan

ANOVA $^{\mathrm{a}}$

\begin{tabular}{lccccc}
\hline \multicolumn{1}{c}{ Model } & Sum of Squares & Df & Mean Square & F & Sig. \\
\hline Regression & 22,255 & 2 & 11,127 & 0,801 & $0,000^{\mathrm{b}}$ \\
\hline Residual & 402,714 & 29 & 13,887 & & \\
\hline Total & 424,969 & 31 & & & \\
\hline
\end{tabular}

Sumber: Data primer yang diolah, 2020

Tabel 5. Hasil uji koefisiensi determinasi (R2)

Model Summary ${ }^{\mathrm{b}}$

\begin{tabular}{ccccc}
\hline Model & R & R Square & Adjusted R Square & Std. Error of the Estimate \\
\hline 1 & $0,229^{\mathrm{a}}$ & 0,520 & $-0,013$ & 3,726 \\
\hline
\end{tabular}

Sumber: Data primer yang diolah, 2020

Berdasarkan tabel 5. Uji Koefisiens Determinasi $\mathrm{R}$ Square sebesar 0,520. Hal ini menunjukan bahwa variabel kompensasi (X1) dan variabel Motivasi kerja (X2) dipengaruhi sebesar 52\% oleh kinerja karyawan. Sedangkan sisanya dipengaruhi $48 \%$ dapat dijelaskan oleh variabel lain yang tidak dapat diteliti dalam penelitian ini.

\section{Pengaruh Kompensasi Terhadap Kinerja Karyawan}

Berdasarkan hasil analisis menunjukkan bahwa variabel kompensasi (X1) memiliki nilai signifikan 0,000 pada tingkat kesalahan 0,05. Hasil menunjukkan bahwa secara parsial variabel kompensasi (X1) memiliki nilai singifikan lebih kecil dari tingkat kesalahan $(0,000>0,05)$. Yang artinya variabel kompensasi berpengaruh secara parsial terhadap kinerja karyawan (Y). Penelitian ini sejalan dengan Wijaya dan Andreani (2015) dan
Yuningsih, dkk (2020). Dalam penelitiannya menunjukkan bahwa kompensasi berpengaruh positif terhadap kinerja pegawai 0,000 pada tingkat kesalahan sebesar 0,05 .

Penelitian ini sama dengan penelitian yang dilakukan oleh Pudjo Wibowo (2018) yang menyatakan bahwa kompensasi secara parsial berpengaruh positif dan signifikan (nilai t hitung kompensasi 2.843.> t tabel 1,984 dan .0005 < 0.05 terhadap Kinerja Karyawan pada PT. Indoraya Internasional di Yogyakarta.

Hal ini menunjukan bahwa kompensasi sangat mempengaruhi kinerja karyawan yang bekerja pada PT. Sinar Suri Toyota Manokwari. Sehingga Kompensasi perlu dikelola dan diatur dengan sebaik mungkin demi menciptakan suasana yang kondusif dalam meningkatkan dan mempertahankan kinerja karyawan. Karena kompensasi adalah salah satu alternatif yang 
menjadi perhatian khusus pada PT. Sinar Suri Toyota Manokwari.

\section{Pengaruh motivasi kerja terhadap kinerja karyawan}

Berdasarkan hasil pengujian menunjukkan bahwa variabel motivasi kerja (X2) memiliki nilai signifikan 0,032 pada tingkat kesalahan 0,05 . Hasil uji t menunjukkan bahwa secara parsial variabel motivasi kerja (X2) memiliki nilai signifikan lebih kecil dari tingkat kesalahan $(0,032>0,05)$. Yang artinya variabel motivasi kerja berpengaruh secara parsial terhadap kinerja karyawan (Y).

Penelitian ini sejalan dengan Pudjo Wibowo (2018), dalam penelitiannya menunjukkan variabel motivasi secara parsial berpengaruh positif dan signifikan (nilai $\mathrm{t}$ hitung motivasi 2.373. $>\mathrm{t}$ tabel 1,984 dan $.020<0.05$ terhadap kinerja karyawan pada PT. Indoraya Internasional di Yogyakarta.

Hal ini menunjukan bahwa motivasi sangat penting dalam suatu perusahaan. Seorang manajer yang memiliki motivasi yang tinggi akan mempengaruhi kinerja manajerial menjadi lebih tinggi. Sebab motivasi adalah salah satu alternatif untuk mendorong dan memberikan arahan kepada kinerja karyawan untuk melakukan tugas dan tanggungjawab yang diberikan sesuai dengan prosedur dan mekanisme kerjanya.

\section{Pengaruh kompensasi dan motivasi kerja terhadap kinerja karyawan}

Berdasarkan hasil pengujian yang dilakukan menunjukkan bahwa variabel kompensasi (X1), motivasi kerja (X2) secara simultan mempunyai pengaruh terhadap Kinerja Karyawan PT. Sinar Suri Toyota Manokwari (Y). Hal ini ditunjukkan dengan nilai signifikansi $\mathrm{F}$ lebih kecil dari nilai alpha $(0,000<0,05)$. Hasil uji $R$ Square $\left(R^{2}\right)$ berdasarkan hasil penelitian ini diperoleh sebesar angka 0,520. Hal ini menunjukkan bahwa variabel kinerja karyawan $(\mathrm{Y})$ dapat dijelaskan oleh variabel kompensasi (X1), motivasi kerja (X2), 52\% sedangkan sisanya $48 \%$ dijelaskan oleh variabel-variabel diluar penelitian.

Dari hasil penelitian diatas dapat disimpulkan bahwa variabel kompensasi (X1) dan variabel motivasi kerja (X2), secara simultan berpengaruh terhadap kinerja karyawan (Y) PT. Sinar Suri Toyota Manokwari. Apabila kompensasi yang diberikan kepada kinerja karyawan sesuai dengan apa yang diinginkan karyawan dan motivasi kerja yang sangat membangun dan meningkatkan semangat kerja karyawan hal ini juga akan berpengaruh terhadap kinerja perusahaan secara keseluruhan yang nantinya akan mempengaruhi masa depan perusahaan untuk menjadi perusahaan yang semakin lebih baik. Didalam perusahan dibutuhkan seorang manajer untuk mengatur dan mengelola aset perusahan. Peran manajemen dilakukan dengan cara memberikan kompensasi sesuai dengan apa yang dihasilkan karyawan jika karyawan bisa menerima kompensasi yang diberikan perusahaan sesuai dengan kualitas dan kuantitas maka karyawan akan lebih giat lagi dalam menyempurnakan pekerjaannya. Sehingga didalam suatu perusahan kompensasi dan motivasi kerja mempunyai pengaruh positif dan signifikan terhadap kinerja karyawan PT. Sinar Suri Toyota Manokwari.

\section{KESIMPULAN}

Berdasarkan klasifikasi masalah hingga hasil dan pembahasan penelitian dengan menggunakan aplikasi SPSS 22 maka disimpulkan bahwa variabel kompensasi (X1) dan variabel motivasi kerja (X2) secara parsial (Uji t) dan secara simultan (Uji F) mempengaruhi kinerja karyawan pada PT. Sinar Suri Toyota Manokwari berdasarkan uji hipotesis dengan nilai signifikan lebih kecil dari taraf kesalahan 0,05. Maka H0 ditolak dan Ha diterima.

Penelitian ini terbatas pada kompensasi dan motivasi kerja, bagi peneliti selanjutnya dapat menambahkan variabel lingkungan kerja, stres kerja, kepuasan kerja variabel intervening. Secara konsep, pemberian kompensasi dan motivasi kerja berjalan sesuai yang dengan yang diharapkan (tepat sasaran) dan tidak menyimpang pelaksanaannya sudah pasti kinerja seorang karyawan dan kinerja perusahaan akan meningkat. Namun pemberian kompensasi dan motivasi kerja tidak sesuai dengan yang diharapkan (salah sasaran) maka akan terjadi suatu masalah dalam pelaksanaannya. Sehingga perlu ada tatanan kontrol yang baik dalam membina, mengatur, serta mengelola sumber daya manusia dengan seefektif dan seefesiensi mungkin demi menciptakan suasana yang nyaman dan kondusif di lingkungan kerja. 


\section{DAFTAR PUSTAKA}

Bangun, Wilson. 2012. Manajemen sumber daya manusia. Jakarta. Penerbit Erlangga

Buchari, Alma. 2007. Manajemen Pemasaran dan dan pemasaran jasa. Edisi Revisi. Bandung. CV.Alfabeta.

Bungin, Burhan. 2015. Metode Penelitian Sosial dan Ekonomi. Cetak ke-2. Jakarta. Penerbit Prenadamedia Grup.

Dessler, Gary. 2015, Manajemen Sumber Daya Manusia, Jakarta. Salemba.

Ghozali, Imam, 2009, Aplikasi Analisis Multivariate dengan Program SPSS, Semarang. UNDIP.

Gibson, Donnelly, Ivancevich. 1997. Manajemen. Edisi Jilid 2. Penerbit Erlangga.

Hasibuan, Melayu S.P. 2007. Manajemen Sumber Daya Manusia Perusahan. Bandung. PT. Bumi Aksa.

Mangkunegara, Anwar Prabu. 2008, Manajemen Sumber Daya Manusia Perusahaan, Bandung. Rosda.

Mondy, R.W. 2008. Manajemen Sumber Daya Manusia, Edisi Kesepuluh. Jakarta. Penerbit Erlangga.

Mulyadi. 2016. Sistem Informasi Akuntansi. Jakarta. Salemba Empat.
Solihin, Ismail. 2009. Pengantar Manajemen. Jakarta. Penerbit PT. Gelora Aksara Pratama.

Sugiyono. 2012. Metode penelitian kuantitatif dan kualitatif, dan $R \& D$. Catatan ke- 17. Bandung. Penerbit Alfabeta.

Sutrisno, Edy. 2009. Manajemen Sumber Daya Manusia. Edisi Pertama. Jakarta. Prenadamedia Group.

Veitzhal Rivai, Mansyur Ramly, Tobi M, Willy A. 2018. Manajemen Sumber Daya Manusia Untuk Perusahaan. Edisi ketiga. Cetak kedelapan. Jakarta. Penerbit PT. Rajagrafindo Persada.

Wibowo, Pudjo. 2018. Pengaruh Kompensasi dan Motivasi Terhadap Kinerja Karyawan Pada PT. Sinar Jaya Abadi Bersama. Jurnal AGORA, Vol. 2, No. 2.

Wibowo. 2007. Manajemen kinerja. Jakarta. PT. Raja Grafindo Persada.

Wijaya, Tanto, Andreani. 2015. Pengaruh Kompensasi dan Motivasi Terhadap Kinerja Karyawan (Studi Kasus PT. Indoraya Internasional Yogyakarta)

Winardi. 2002, Motivasi dan Pemotivasian dalam manajemen. Jakarta. PT. Grafindo Persada.

Yuningsih, Erni, dkk. 2020. Pengaruh Motivasi dan Kompensasi Terhadap Kinerja Karyawan Pada Divisi Produksi PT. Kusuma Kaisan Sentul-Bogor. Jurnal Visionida, Vol.6, No.1. 